\title{
Suppression Control of Inverse Response for A Multi-Agent Type Non-Minimum Phase System 正 加藤 傶（阪大）
}

\section{Makoto Katoh, Osaka Institute of Technology}

\begin{abstract}
First of all, the $2^{\text {nd }}$ or $2^{\text {nd }}$ approximated non-minimum phase objects were requested, it limited as the agent system in this thesis. We obtained an analytical solution on the amount and the over-shoot time of an inverse-response. Then, a strategy of the inverse-response suppression control by the adjustment of inherent parameters was requested about it. Next, if an inverse-response of the worst damping agent was suppressed in the case of those parallel multi agents systems, it was shown that it was enough for them.
\end{abstract}

KEYWORD: Non'minimum Phase System, Inverse Response Suppression Control

\section{1.はじめに}

非最小位相系の制御問題の解決のために線形系で は最適レギュレータによる非干涉制御 ${ }^{1}$ が、多入力多出 力の特定の非線形系では特異摂動系への変換手法等 が研究されている2゙。しかし、それらが逆応答の抑制に も有効であるとは直接的に述べられてはいなかった。

一方、多くの分野において、分散人工知能の柱として マルチエージェントシステムの研究の有用性が注目さ れている ${ }^{3)}$ 。そこでは、自律性、適応性、社会性を兼ね 備えた狭義の高機能エージェントから、それらのうちの 1 つでも有すれば良いとする広義の簡易エージェントまで、 さまざまなエージェントが活躍している。その実体もロボ ット、タスク、ソフト、状態方程式など多くの種類がある。

本稿では非自律的であるが並列分散系の構成要素

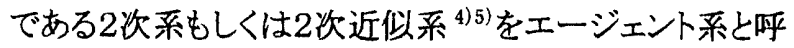
び、それらが並列に結合した系をマルチエージェント系 と見なす。そして、各エージェント系の逆応答時間と逆 応答量を解析的に求めれば、各エージエント系の固有 パラメタの調整戦略からマルチエージェント系の逆応答 抑制制御の社会性のある指針が得られることを示す。

\section{2. 安定な非最小位相遗港交2次系の逆度客}

次のような零点を 1 つ持つエージェント系： を考える。これが過减衰系の場合には逆応答の逆応 $\left[\begin{array}{l}\dot{x}_{1}(t) \\ \dot{x}_{2}(t)\end{array}\right]=\left[\begin{array}{cc}0 & 1 \\ -\omega_{n}^{2} & -2 \varsigma \omega_{n}\end{array}\right]\left[\begin{array}{c}x_{1}(t) \\ x_{2}(t)\end{array}\right]+\left[\begin{array}{c}0 \\ K \omega_{n}^{2}\end{array}\right] u(t)$ $y(t)=\left[1, \frac{c}{\omega_{n}^{2}}\right]\left[\begin{array}{l}x_{1}(t) \\ x_{2}(t)\end{array}\right]$

答時間および逆応答量は次のように解析的に求めら れる。また、この零点が不安定需点 $(c<0)$ であれば、 そのェージェント系のステップ忍答は逆忘答を有す ることを式(2)の正值条件から示すことができる。 逆応答時間はFig. 1 に示すように减衰係数が大き くなる程小さくなり、逆応答量も Fig. 2 に示すよう に減衰係数が大きくなる程小さくなる。 逆志答時間

$$
t_{i}=\frac{1}{2 \sqrt{\varsigma^{2}-1} \omega_{n}} \ln \left(\frac{c\left(\varsigma+\sqrt{\varsigma^{2}-1}\right)-\omega_{n}}{c\left(\varsigma-\sqrt{\varsigma^{2}-1}\right)-\omega_{n}}\right)
$$

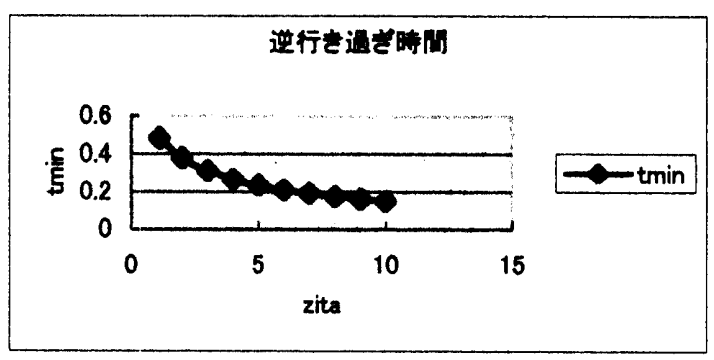

Fig.1 逆応答時間

逆応答量

$$
\begin{aligned}
& y_{i}(t)=K\left\{1+\frac{-c+\left(\varsigma-\sqrt{\varsigma^{2}-1}\right) \omega_{n}}{2 \sqrt{\varsigma^{2}-1} \omega_{n}}\left(\frac{c\left(\varsigma+\sqrt{\varsigma^{2}-1}\right)-\omega_{n}}{c\left(\varsigma-\sqrt{\varsigma^{2}-1}\right)-\omega_{n}}\right)^{\alpha}\right. \\
& \left.+\frac{c-\left(\varsigma+\sqrt{\varsigma^{2}-1}\right) \omega_{n}}{2 \sqrt{\varsigma^{2}-1} \omega_{n}}\left(\frac{c\left(\varsigma+\sqrt{\varsigma^{2}-1}\right)-\omega_{n}}{c\left(\varsigma-\sqrt{\varsigma^{2}-1}\right)-\omega_{n}}\right)^{\beta}\right](3) \\
& \alpha=\frac{-\left(\varsigma+\sqrt{\varsigma^{2}-1}\right)}{2 \sqrt{\varsigma^{2}-1}} \quad \beta=\frac{-\left(\varsigma-\sqrt{\varsigma^{2}-1}\right)}{2 \sqrt{\varsigma^{2}-1}}
\end{aligned}
$$

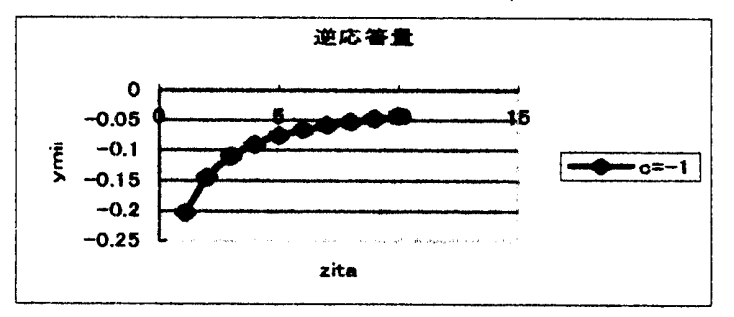

Fig.2 逆応答量

\section{3，逆応答㧕制制御}

\section{1 調整戦略}

逆応答量は固有角速度には無関保に減衰係数を大 きくするほど小さくなるので、逆応答量を所定の值 以下にする减衰保数になるようにフィードバック制 御で調整することができる。それとは無関係に立ち 上がり時間や整定時間をほほ一定に調整するために、 減衰保数を大きくするほど固有角速度も大きくなる ように、固有角速度をやはりフィードバック制御で 調整する 2 自由度制御案が考えられる。元の系が不 足减衰や臨界減衰の場合でも目標とする减衰係数が 過減衰であれば、同様の式が使えるはずである。

結局、発見的な「K 不変かつ $\zeta=\omega n$ 戦略」を採用 
すれば逆态答を抑制しつつ応答速度を維持できる。

3. 2 PDレギュレータによる実現

PDレギュレータを用いた場合に「K不変かつ $\omega \mathrm{n}$ 戦略」を採れば、安定限界パラメ夕空間内の比 例・微分係数は次式で解ける。

$\left(K \omega_{n}^{2}+K c\right) k_{d}^{2}+\left(K \omega_{n}^{2}+2 \varsigma \omega_{n} K c-K c^{2}\right) k_{d}+2 \varsigma \omega_{n}-2 \omega_{n}^{2}=0$

$k_{p}=\left\{\frac{1}{\left(1+k_{d} K c\right)}-1\right\} \frac{1}{K}$

この場合、固有パラメタは決まってしまい、十分 な逆㐫答の抑制は期待できない。「K 不変かつと指定 戦略」を採れば逆応答は㧕制できるが、応答は遅く なると考えられる。結局、定常偏差も無くそうとす ると PD 極指定レギュレータでは自由度が足らない ので、次に二自由度制御について検討する。

\section{3 二自由度制御}

極指定と定常偏差防止を行える二自由度制御には 目標值変換を行う方法と I-PD 制御を行う方法が考 えられるが、調整の容易さや外乱の影皚除去の観点 では積分器を用いた I-PD制御の方が優れている。し かし、閉ループは 3 次系になるので逆応答と固有パ ラメタの関係が複雑である。そこで、K 不変性は積 分制御や目標值変換に任せてしまい、PDレギュレー 夕では「 $\omega_{n}=\zeta$ 指定、すなわち、極指定戦略」を採 ることにすると、2 次系のままで扱える。結局、PD レギュレータの各パラメタは次式で求まるが、安定 性確保のための不等式が存在するので、任意に减衰 係数を指定することはできない。

$$
\begin{aligned}
& K k_{d}=\frac{\left(2 \varsigma \omega_{n}-2 \bar{\zeta}^{2}-c\right) \omega_{n}^{2}+c \bar{\zeta}^{2}}{\left(2 \bar{\zeta}^{2} c-\omega_{n}^{2}\right) \omega_{n}^{2}-\bar{\zeta}^{2} c^{2}}<\frac{1}{-c} \\
& \frac{2 \varsigma \omega_{n}+k_{d} K \omega_{n}^{2}}{-c}>K k_{p}=\frac{\bar{\zeta}^{2}}{\omega_{n}^{2}}\left(1+c K k_{d}\right)-1>-1
\end{aligned}
$$

$\mathrm{K}$ 不変性のための目標值変換は次式になる。

$$
\bar{r}=\left(1+k_{d} K c\right)\left(1+k_{p} K\right) r
$$

この目標値変換による方法は積分器を用いていな いために、サーボの用途ではソフトサーボになるこ とに注意すべきである。

\section{4.マルチエージェント系への拡張}

高次偶数次数系が次のように部分分数展開できた とする。ここでは一般には直列エージェント系が並 列エージェント系として記述できた場合を考察する。

$$
G(s)=K \frac{\prod_{i=1}^{2 m-1}\left(\tilde{c}_{i} s+\tilde{b}_{i}\right)}{\prod_{i=1}^{m}\left(s^{2}+2 \xi_{i} \omega_{n i} s+\omega_{n i}^{2}\right)}=K \sum_{i}^{m} \frac{A_{i} \omega_{n i}^{2}\left(\frac{c_{i}}{\omega_{n i}^{2}} s+1\right)}{s^{2}+2 \xi_{i} \omega_{m i} s+\omega_{n i}^{2}}
$$

このステップ态答はそれぞれの並列サブシステム、 すなわち各エージェント系のステップ応答の重ね合 わせになり、それぞれの逆态答時間は次のようにな る。ただし、少なくても 1 つの $\mathrm{c}_{\mathrm{i}}<0$ とする。

$$
t_{i}=\frac{1}{\left(2 \sqrt{\varsigma_{i}^{2}-1}\right) \omega_{n i}} \ln \left[\frac{\omega_{n i}-\left(\varsigma_{i}+\sqrt{\varsigma_{i}^{2}-1}\right) c_{i}}{\omega_{n i}-\left(\varsigma_{i}-\sqrt{\varsigma_{i}{ }^{2}-1}\right) c_{i}}\right] \text { (10) }
$$

逆応答項のそれぞれの逆応答量も次のようになる。

$$
\begin{aligned}
& y_{i}(t)= K A_{i}\left\{1+\frac{-c_{i}+\left(\varsigma_{i}-\sqrt{\varsigma_{i}^{2}-1}\right) \omega_{n i}}{2 \sqrt{\varsigma_{i}^{2}-1} \omega_{n i}}\left(\frac{c_{i}\left(\varsigma_{i}+\sqrt{\varsigma_{i}^{2}-1}\right)-\omega_{n i}}{c_{i}\left(\varsigma_{i}-\sqrt{\varsigma_{i}^{2}-1}\right)-\omega_{n}}\right)^{\alpha_{i}}\right. \\
&+\frac{c_{i}-\left(\varsigma_{i}+\sqrt{\varsigma_{i}^{2}-1}\right) \omega_{n i}\left(\frac{c_{i}\left(\varsigma_{i}+\sqrt{\varsigma_{i}^{2}-1}\right)-\omega_{n i}}{2 \sqrt{\varsigma_{i}^{2}-1} \omega_{n}}\right)}{c_{i}\left(\varsigma_{i}-\sqrt{\varsigma_{i}^{2}-1}\right)-\omega_{n}} \quad(11) \\
& \alpha_{i}=\frac{-\left(\varsigma_{i}+\sqrt{\varsigma_{i}^{2}-1}\right)}{2 \sqrt{\varsigma_{i}^{2}-1}} \quad \beta_{i}=\frac{-\left(\varsigma_{i}-\sqrt{\varsigma_{i}^{2}-1}\right)}{2 \sqrt{\varsigma_{i}^{2}-1}}
\end{aligned}
$$

これらを重ね合わせた時の逆応答時間は正時間の $t \in\left[\min _{i} t_{i}, \max _{i} t_{i}\right]$ で発生し、重ね合わせ後の最大 值は逆応答項に関する次の不等式で抑えられる。

$$
\min _{i} y_{i}(t) \leq \max y(t) \leq \sum_{i=1}^{m} y_{i}(t)
$$

これらの逆行き過ぎ昷はそれぞれの减衰係数を大き くする程小さくなるが、忠答が遅くなるので、次の ような二自由度 I-PD 制御調整戦略を考える。

1) 各エージェント系の中の最悪减衰系につ

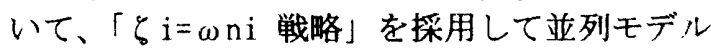
参照型PDレギュレータ等によって調整する。 その他のエージェント系はその調整の下で成り 行きに任せるが、符号が同一であれば同様に改 善されるはずである。

2） K不変性は全体系に対する目標值変換が 難しくなるので積分制御によって保証する。

\section{5. 結}

零点を 1 つ有する二次系をエージェント系とみな して目標值変换法を用いた二自由度極指定 PD レキ ュレータによる非最小位相系の逆応答抑制制御法を 誘導した。同様の効果は同じPDレギュレ一多を用い た I-PD 制御による二自由度制御でも得られる。

高次系をこれらの並列系一変換後の最悪减衰エ… ジェント系に対する調整を行えば、マルチエージェ ント系にも十分な効果が得られることを示した。

\section{㖣辞}

本研究に対して貴重なサジェスチョンを頂いた大 阪大学の古荏教授と池田教授および重要な議論をし てくれた大阪工大の田中学君に感謝致します。 参考文献

1. 鈴木・小林・藤田：非最小位相系に対する最適 レギュレータの極限形式を用いた近似非干涉制 御、電学論 C, 119-3、380/386 (1999)

2. JuI1 Lee and In-Joong Ha:A Novel Approach to Control of Nonminimum-Phase Nonlinear Systems, IEEE Trans. On AC, Vol. 47-9, 1480/1491 (2002)

3. G. M. P. O'Hare and N. R. Jennings,: "Foundations of Distributed Artificial Intelligence", Sixth-Generation Computer Technology Series, Wiley-Interscience, (1996).

4. 高橋：システムと制御、岩波 (1986)

5. 嘉納他 : 動的システムの解析と制御、コロナ社 (1996) 